\title{
Commercial and Legal Regulation of Advisory Services in the Ukrainian Agrarian Business Prospect Reform
}

\author{
By Inna Kovalchuk ${ }^{1}$, Olesia Melnyk ${ }^{2}$, Anna Pakhomova ${ }^{3}$
}

\begin{abstract}
The article is devoted to theoretical and practical aspects of reforming the commercial and legal regulation of advisory services in the agrarian business of Ukraine. The characteristic of agricultural advisory activity model structure in Ukraine is given, which currently consists of several levels of subjects of such activity: the first level - national, nationwide; second level - regional; third level local; fourth level - personal. Particular attention is given to the legal analysis of the essence of "advisory services in the agricultural business" as a type of commercial activity, and taking into account the provisions of the current legislation, it is proved that in its essence and legal nature agribusiness advisory is an institution of commercial law. The article examines and characterizes a typical business agreement for the provision of advisory services in the agricultural sector of the Ukrainian economy, the essential conditions for this type of contracts are given, and their characteristics are defined. The advisory activity is seen as an effective instrument of state agrarian policy.
\end{abstract}

Keywords: commercial and legal regulation, advisory service, advisory activity, agrarian business, advisor, expert consulting services, consulting

\section{Introduction}

Agricultural advisory activity in the Ukrainian agrarian business has already established itself as a scientific, economic and political phenomenon. The term «advisory activity» should be understood as informational, consulting, organizational, managerial, innovative, educational and other activities necessary for the full implementation of the tasks assigned to the agrarian and industrial complex of Ukraine.

Agricultural advisory services have been provided at the level of most regions of Ukraine, which are increasingly proves their importance and the need for the effective functioning of the agricultural sector in the country. At the same time, it is quite obvious that there is no legal regulation for this type of economic activity. Even the adoption of the Law of Ukraine «On Agricultural Advisory Activities» (Verkhovna Rada of Ukraine, 2004) has not resolved all controversial issues concerning the content, subjective composition and economic and legal mechanism of its implementation. Therefore, the problems of economic and legal regulation of agrarian-consulting activity is one of the unregulated and underexamined directions in the Ukrainian economic and legal science.

| $1 \mathrm{PhD}$ in Law, Associate Professor, Head of the Department of Public Law of Bila Tserkva National Agrarian University, Ukraine

${ }^{2} \mathrm{PhD}$ in Law, Senior lecturer in theoretical-legal and socio-humanitarian disciplines Bila Tserkva National Agrarian University, Ukraine

${ }^{3} \mathrm{PhD}$ in law, Associate Professor, Head of Department of Civil law disciplines of the Bila Tserkva National Agrarian University, Ukraine 
The current agrarian legislation effectively makes it impossible for independent advisory activity by individual entrepreneurs. It would be more expedient to give them such an opportunity at the legislative level, which will undoubtedly lead to a positive effect, which will be reflected in the main direction of stimulating the development of small business in the agricultural sector.

The main reasons for the failure of modern agricultural legislation in the field of advisory services should to some extent contribute to the stabilization and raising of agricultural production, and at the same time to the exit of this industry from the protracted crisis: (a) The Cabinet of Ministers of Ukraine and in departmental normative acts; (b) a considerable number of legal acts, which obviously follows from the first, as sources of agrarian law, which have different legal force. The adoption of a codified normative act as a law, which should be the most rational means of regulating agrarian and related relations, will help to overcome these problems. It is advisable to separate the legal position of agricultural advisory activity in the agricultural sector of the Ukrainian economy by a separate unit.

\section{Review of Literature}

Kropivko M.F., proves that the infrastructure of agricultural advisory services will be made up of the state agricultural advisory system, non-state public agricultural advisers, expert advisers and private consultants (Kropivko M., 2014).

According to Il'kiv, L.A. and Vovk N.S., the agricultural advisory service is considered in modern terms, mainly as organizational information sharing and purposeful transfer of skills (Ilkiv L., Vovk N., 2011).

Roven $\mathrm{V}$. under advisory activity means purposeful activity on the system of new knowledge and professional skills formation, which contribute to increase of efficiency of agrarian business (Roven V., 2016).

According to Demyshkevich G.M., agricultural counseling is the activity of advisers providing professional advisory services, which are recommendatory and help representatives of the agricultural business and population in goals and objectives realization by solving different kinds of problems, identifying and using new opportunities, also identifying and exploiting new opportunities, implementing changes and study (Demishkevich G., 2009).

Aristova I.V, and Urkevich V.Yu. are noted the following features of agricultural counseling in their study of the legal nature of agricultural advisory services: 1) agricultural advisory service is a public service; 2) agricultural advisory activities are broadly related to the provision of administrative, information and advisory services; 3 ) a comprehensive legal institute of inter-branch agricultural advisory activity is formed; 4) the establishment and development of the agrarian and commercial legislation institute the institute of legal regulation of agricultural advisory activities (Aristova I., Urkevich V., 2013).

\section{Objectives of the Study}

The purpose of the study is to establish the nature, content and mechanisms of 
commercial and legal regulation of agricultural advisory activity in Ukraine on the basis of a comprehensive analysis of theoretical principles of commercial law and process, law enforcement activities of state authorities and local self-government, economic entities, and to develop science-based proposals and recommendations for its improving.

\section{Research Methodology}

The elaboration of the chosen topic is based, first of all, on the provisions of the general theory of law, taking into account the latest achievements of the sciences of commercial, commercial-procedural, agrarian and international law. In accordance with the purpose and objectives of the study, a rational set of methods of cognition theory and comparative legal analysis were used.

\section{Need of Study}

One of the reasons for the occurrence of commercial obligations is commercial contracts, by which the links between the business entities are mediated, as well as between them and other participants in the commercial relations.

The nature of the commercial contract, including the contract for the provision of agricultural advisory services, is characterized by the acceptance by one party of a certain obligation, which can be defined as a statement or assurance made to another person, ascertaining a certain state of affairs or establishing that the person performs or refrain from taking any specific action, and the right granted to another person, to demand the execution of such a statement.

The obligation expresses more than a simple intention message because it means the debtor's consent becomes obliged to the person who made the statement. It also cannot be reduced to an offer to take any particular action, since the offer must be accepted by the creditor. Thus, we can conclude that a public offer of agricultural advisory services (advertising) cannot be considered as a liability.

The contract for the provision of agricultural advisory services is commercial and has several features:

1) is consensual, the moment of conclusion coincides with the moment when the parties reach agreement on all its essential terms;

2) the main results of the contract for the provision of agricultural advisory services, in particular consulting services, are the result of the intellectual work of a specialist advisor, which may not be expressed in material form;

3) due to the lack of legal regulation of the contract for the provision of agricultural advisory services, mandatory control over their implementation by law is not provided, although it is possible at the mutual request of the parties to the contract;

4) the subject matter of agricultural advisory activity, with the consent of the other party, may involve other specialists - third parties, as subcontractors;

5) the financial result of the action is not foreseen in the contract for the payment of agricultural advisory services, and therefore, the service itself is payable, not its result. According to this stage of delivery and acceptance of services provided for this contract, as a rule, are not allocated. In this regard, it is the duty of the contractor - the agricultural 
advisory entity to perform certain actions or activities, and the customer duty is to pay them.

Therefore, it would be a mistake to combine the legal regulation of payment services in general and the provision of agricultural advisory services. These two concepts relate to each other as a general and fraction.

An agricultural advisory service contract is a type of contract for the provision of payment services, since the latter may relate to services in all spheres of public life and business. Even agricultural advisory services are different in themselves. In particular, some are provided to consumers in civil traffic and are governed by civil law, while others, which are more important, from the perspective of those involved in the deal, resources and the complexity of the issues are taking an increasing share in practice business entities.

As rightly points out Zamoyskiy I., organizational functions are inherent in any commercial contract, but there may be a different ratio of organizational and property elements in the contract. In some cases, the commercial contract content where the organizational moment dominates, in others, it plays the role of communication in property relations (Zamoysky I., 1982).

Commercial contracts for agricultural advisory services may play a particular role. It depends on the subjects of these contracts. For example, on the one hand, for an agricultural enterprise engaged in agricultural production, the contract for a brief overview of environmental law, made by a law firm, is not a contract, which directly ensures the maintenance of its production process. Thus, it can be concluded that the commercial agreement for the provision of agricultural advisory services can act as an estate, so and auxiliary.

As noted above, the law does not define the concept a commercial contract for the provision of agricultural advisory and consulting services. However, the Commercial Code of Ukraine Verkhovna Rada of Ukraine, 2003) made an attempt to settle a similar agreement through an agency agreement.

According to Part 3 of Article 180 of the Commercial Code of Ukraine (Verkhovna Rada of Ukraine, 2003), an agreement is considered concluded when the parties have reached agreement on all its essential terms. The essential terms of the contract include the conditions necessary to fulfill the obligations and provided for by current legislation or which is required by one of the parties to the contract. It is imperative that the parties of the business agreement agree on the essential conditions of the subject, price and term of the contract.

Thus, the content of any commercial contract, in particular contract for the provision of agricultural advisory services are agreed essential conditions for the services to be provided.

These terms are the result of mutual agreement between the parties. However, the practice of concluding such contracts, including foreign, developed some tactics when they are assembled. Thus, according to many experts, the contract concluded between the client and the subject of agricultural advisory activity may contain the following essential conditions:

- subject matter of the contract (purpose, description of service, start date, calendar schedule, scope of service); 
- results of services provided and reporting (documentation and reports, which should be passed to the client for confirmation services provided);

- contribution of the agricultural advisory entity and the client (other types of contributions);

- fees and costs (billing fees, reimbursable expenses for the agricultural advisory entity activity);

- terms and procedures of calculations;

- professional responsibilities (transfer of confidential information, avoidance of conflicts of interest and other aspects);

- copyright (content, scope and order of distribution between the client and the agricultural advisory entity, covers the products of the agricultural advisory entity's work while performing a client task);

- liability (liability of the agricultural advisory entity for the damage caused to the client, limitation of liability);

- conditions and procedure use of labor and services of the third party executors;

- terms of termination or revision of the contract (grounds, terms, mechanisms);

- arbitration (jurisdiction, dispute settlement procedure);

- contract term.

Summing up, we can state that a commercial contract for the provision of agricultural advisory services is generally paid, bilateral, binding and consensual. Its main distinguishing features are:

a) the object of a commercial contract for the provision of agricultural advisory services are other services than those provided to citizens in civil legal relationships;

b) in the commercial activities of the entities, this contract may serve as the main contract and ancillary;

c) this commercial contract is a "regulated" contract, in which one party (contractor or consultant) undertakes to provide consulting services and the other (customer or client) to accept and pay for them;

d) a commercial obligation under the contract for the provision of agricultural advisory services predicts the result of intellectual, creative activity;

e) a contract for the provision of agricultural advisory services concerns not only private but also public interests. The variety of commercial activities, including in the field of agricultural advisory services, causes a wide range of commercial contracts. Each such commercial contract is characterized by general and specific features, which give reason to carry out their classification.

For the purpose of this study it is worth making a conceptual distinction between business services such as consulting (direct consulting services) and business training (educational services). Sometimes it is difficult to make this distinction, because counseling functions are often logically continues their teaching functions, and, as practice shows, often within the framework of one training and counseling center. Except the natural desire of agricultural commodity producer to be consulted where they have undergone quality business training, the integration mentioned above is stimulated by factors of a purely economic plan: consulting activities are more cost-effective than providing educational services and allow "business schools" to continue and expand its activities. 
When we differentiate advisory and educational services we assume that learning (both in-person and distance) is system-software within the framework of long-term preparation of both the economic and professional plan. As for consulting (or advisory) services, they are more discrete, even one-off, substantially more private, purposeful and may be required by the consumer of agricultural advisory services, first of all agricultural commodity producer - entrepreneur, at almost any stage of his activity from opening to registration of activity or bankruptcy termination.

Depending on the classification of agricultural advisory services we can also talk about the discrepancy of commercial contracts for the provision of such services. Under the subject of agricultural advisory services contracts are divided into legal consulting contracts, accounting and auditing consulting, financial, credit and investment consulting, engineering and technical consulting, marketing, consulting on social and labor relations, business security consulting.

Continuing the classification of contracts, we can talk about dividing them by source of agricultural advisory services - universal services in various subjects (usually provided on behalf of large consulting firms) and specialized consulting services in specific subjects (legal, tax, marketing, technical and innovative, customs, etc., provided on behalf of small firms and individual private consultants).

Depending on the access of agricultural advisory services to the activity of the consumer of services - «external» consulting or documentary, when the advisers only analyze the primary accounting and other information about the activity of the enterprise, and «internal» consulting, when the advisers, together with the analysis of the primary information, are directly involved in the management of the consumer enterprise as a whole or practically one of the parties to its daily activities for some time. However, this form of consulting has not yet become widespread in management practice in Ukraine.

Internal counseling involves the permanent work of an advisor in the regular office staff of the entity-consumer consulting firm. Theoretically, it cuts the cost of the enterprise (the salary of the advisor is usually less than his fees) while preserving the benefits of the project method of consulting. However, in practice, the following points should be considered:

1) Unbiased opinion of the advisor - one of the benefits of third-party consulting is devalued to some extent. The advisor knows that his work ends with the project and his single purpose is to create a quality product, through external consultation. It is important for an internal consultant to determine his place in the structure, so his purpose is double - a quality product and a convenient own position. It is easy to guess that sooner or later, these goals will contradict and impartial thought will suffer.

2) Independence of an opinion - the second major advantage in external counseling can also be questioned.

3) Advisor qualification growth, giving him a diverse experience is slowed down by internal counseling.

4) Delegation of powers to the advisor, those that duplicate management functions, or the recognition of his right of decisive thought may lead to the creation of a second center of power in the enterprise. This list of types and forms of agricultural advisory services cannot be considered exhaustive, since it is dictated by the life itself and development of society, taking into account its needs. Obviously, this list will become 
wider and the quality of service will increase as the market becomes more competitive.

\section{Agricultural Consulting is Part of the EU-Ukraine Association Agreement}

The establishment of an agricultural advisory system in Ukraine is an integral part of the European integration process.

Article 404 of the Association Agreement between Ukraine and the European Union provides that cooperation between the Parties in the field of agriculture and rural development should cover, in particular, the dissemination of knowledge through educational and information activities and the promotion of innovation through research and promotion of the advisory system. agricultural producers.

Supporting agricultural advisory activities in developed countries is one of the most important tools for stimulating rural development. Increasing agricultural production, stimulating economic growth, improving the well-being of the rural population, combating poverty, eliminating social problems, the rational use of natural resources are the main components of rural development, which is focused on advisory services of developed agricultural countries in the region. Peace.

Ensuring stable profitable agriculture in Ukraine, effectively functioning advisory activity in the agrarian sphere will facilitate the formation of fundamentally new industrial relations between agricultural producers, other participants in the agrarian market and public authorities, agrarian education and science, as well as low

Conditions for providing socially-oriented counseling services are defined in the Cabinet of Ministers of Ukraine, approved on September 19, 2007 No. 1131 of the Procedure of using the funds provided in the state budget for state support of the agricultural advisory service (Cabinet of Ministers of Ukraine, 2007).

Lists of socially-oriented consulting services, the amount of their funding for each contractor and the area in which the services are provided are presented in the action plans, which are approved annually by the relevant structural units of regional state administrations. Provision of socially-oriented consulting services, which is carried out in accordance with the plan of events, is formalized by an act signed by the subject of agricultural advisory activity, the head of the village (settlement) or district council, the head of the respective structural unit of agro-industrial development of the regional state administration and the consumer of consulting services.

Budget funds are used to pay for the most effective consulting services: conducting training seminars, individual consulting services, publishing and distribution of printed matter, demonstrating forms and methods of work of business entities.

In the European Union, the importance of the agricultural system the deliberations were reflected in the legal acts of the member countries of the organization, yes and in the legal acts of the European Union.

Council Regulation (EU) No 73/2009 establishing common rules for schemes direct support for farmers under the Common Agricultural Policy and on establishing some support schemes for farmers, amending Regulation (EU) Regulation (EC) No 1290/2005, (EU) 247/2006, (EU) 378/2007 and repeals Regulation (EU) 1782/2003 provides: «To help farmers meet modern standards, high-quality agriculture requires that EU Member States continue use the comprehensive farmers' advisory system provided 
for in the Regulation (EC) 1782/20038. The farmers' advisory system should help farmers in getting more information on material flows and processes on farms that belong to ecology, product safety, health and animal welfare without any impact on their commitment to compliance with standards and their responsibility» (Council Regulation, 2009).

\section{Conclusion}

Despite the considerable support of agricultural advisory services in international technical assistance projects in many countries, including in Ukraine, this assistance has not been used effectively: advisory services have either ceased operations or minimized their activities without changing the institutional environment. Therefore, the need to change the institutional environment comes to the fore.

Agricultural advisory organizations are hardly supported by the state or the level of existing support cannot ensure the sustainability of the advisory system.

At the same time, it is difficult to switch to exclusively paid services for the rural population because of its total poverty.

Actually, total poverty, lack of institutes, especially informal ones, as well as lack of adequate information and consulting support are the main reasons for the slowdown of the development of agricultural service cooperatives in Ukraine, pointing to the existence of its formal support by the authorities. Therefore, the formation of effective mechanisms for state support for agricultural advisory becomes almost the main task.

In such a situation, consultants, consulting companies do not consider consulting as a profitable business. Of this, small farmers in Ukraine are the first to lose.

Thus, it is understandable the nature of agricultural advisory activity as a type of intellectual activity, the main task of which is data collecting, systematization and processing. Also, development of specific justifications and recommendations for development and use scientific, technical and organizational-economic data solving problems of business activity of the counterparty. On the basis of the analysis of the nature of agricultural advisory activities, because of their specific features, the article proves compliance with its criteria of economic activity and, consequently, its subordination to the rules of the economic law itself.

Besides, regulation of agency relations of commercial law cannot be applied to agricultural advisory services in the field of business, so these services require additional special regulation.

The foregoing indicates that, in practice, the provision of agricultural advisory services raises many issues that need legislative regulation. Due to the lack of legislation in the rules governing advisory relations, which is by its origin, the main content of agricultural advisory activity.

Therefore, the contract for the provision of agricultural advisory services should contain the following essential conditions: the subject of the contract; results of services provided and reporting; the contribution of the agricultural advisory organization and the client; fees and expenses; terms and payment procedure; professional duties; copyright; contractual liability; use of the works and services of third parties conditions; cancellation terms of the contract or its renegotiation; arbitration; tenor of the contract. 
In view of Ukraine's integration into the European Community, including its accession to the WTO, it is important to enshrine in the recent legislation of Ukraine the legal provisions governing international cooperation in the field of production and sale of agricultural products and to separate the provisions of agricultural advisory activity in the agricultural sector Ukraine, taking into account the experience of the European Union countries.

It is appropriate to amend the Law of Ukraine «On Agricultural Advisory Activities» (Verkhovna Rada of Ukraine, 2004) by specifying the status of agricultural advisory services in relation to the provision of information and advisory services, defining the procedure for depriving or withdrawing such status.

It is necessary to develop and approve by the Government the National Program of Agricultural Advisory Activities in Ukraine and the Concept of Formation of the State Agricultural System for the Period up to 2025.

It may be timely to develop the Model Regulations on Agricultural Advisory Service, taking into account the organizational and legal form and ownership as a legal entity, with subsequent approval by the relevant competent body - the Cabinet of Ministers of Ukraine. It is also necessary to develop an Appropriate Provision for the Agricultural Advisory Service as a structural unit of an agricultural educational institution or research institution, having approved it in the Cabinet of Ministers of Ukraine, which will allow to choose the way for effective and qualitative training of personnel in the agricultural advisory system.

By the time the regions are saturated with qualified agricultural advisers and the harmonization of the terms of agricultural advisory services, it would be advisable for the government to develop approximate models of contracts for different areas of their provision to the following major customer groups: (a) private farms, (b) farms, (b) farms different organizational and legal forms of ownership and management; ospodarskoyu activities, (e) enterprises, which are harvested, redesign and sell agricultural products; (h) suppliers of material and technical resources, (f) financial institutions, (e) rural territorial communities, (i) local governments, (i) local public authorities, (k) non-governmental organizations, other non-governmental and non-profit organizations and other customers.

\section{References}

Anson V. (1984). Contract Law: Trans. with English. Law. Lit., 1984. 463.

Aristova I., Urkevich V. (2013). Legal nature of agricultural advisory activity. Administrative law and process. 2013. № 4. Available from: http://applaw.knu.ua/index.php/arkhiv-nomeriv/2-42013/item/186-rights-nature-silskohospodarskoyi-doradchoyi-diyalnostiaristova-iv-urkevych-v-yu [Accessed 04.05.2020].

Bezus R.M. (2014). Organizational and economic principles of effective development of organic agricultural production: monograph. Dnipropetrovsk: Lizunov Press, 2014. 380.

Cabinet of Ministers of Ukraine (2015). On approval of the State Target Concept programs for the development of the agrarian sector of the economy for the period up to 2020. Available from: https://www.kmu.gov.ua/ua/npas/248907971 [Accessed 04.05.2020].

Cabinet of Ministers of Ukraine (2007). Procedure of using the funds provided in the state budget for state support of the agricultural advisory service. Available from: https://zakon.rada.gov.ua/laws/show/1131-2007-\%D0\%BF [Accessed 04.05.2020]. 
Cabinet of Ministers of Ukraine (2011). Approving the Regulations on the Registers of Agricultural Advisory Services, Agricultural Advisers and Expert Advisers. Available from: https://zakon.rada.gov.ua/laws/show/897-2006-\%D0\%BF [Accessed 04.05.2020].

Cabinet of Ministers of Ukraine (2011). Approving the Regulations on the Registers of Agricultural Advisory Services, Agricultural Advisers and Expert Advisers. Available from: https://zakon.rada.gov.ua/laws/show/897-2006-\%D0\%BF [Accessed 04.05.2020].

Cabinet of Ministers of Ukraine (2014). Questions from the Ministry of Economic Development, Trade and Agriculture. Available from: https://zakon.rada.gov.ua/laws/show/459-2014-\% $\%$ D0\%BF [Accessed 04.05.2020].

Cabinet of Ministers of Ukraine (2008). On the use in 2008 of the funds provided in the State Budget for state support of the agricultural advisory service. Available from: https://zakon.rada.gov.ua/laws/show/67-2008-\%D0\%BF [Accessed 04.05.2020].

Council Regulation (EC) No $1782 / 2003$ of 29 September 2003. Available from: http://eurlex.europa.eu/LexUriServ/LexUriServ.do?uri=OJ:L:2003:270:0001:0069:EN:PDF [Accessed 04.05.2020].

Council Regulation (EU) No 73/2009 of 2009 establishing common rules for direct schemes support for farmers under the Common Agricultural Policy and on the establishment of certain support schemes for farmers amending Regulation (EU) Regulation (EC) No 1290/2005, (EU) 247/2006, (EU) 378/2007 and repealing Regulation (EU) 1782/2003. Available from: $\underline{\text { http://base.consultant.ru/cons/cgi/online.cgi?req }=\text { doc;base }=I N T ; n=55065} \quad$ [Accessed 04.05.2020].

Demishkevich G. (2009). Organizational and economic bases of agricultural consulting system development. AIC: Economics and Management. 2009. №8. 32-35

Gafurova O. V. (2011). Diversification of agriculture under the legislation of the European Community and Ukraine. Current tendencies of development of national legislation of Ukraine. Kiev: NUBiPU Publishing Center. 2011. 269-271.

Ilkiv L., Vovk N. (2011). Features of development and functioning of the system of advisory services of the world. Development of the state system of advisory services and its educational programs (collection of articles). NULES of Ukraine 2011. Available from: http://elibrary.nubip.edu.ua/9991/1/Theses_address.pdf [Accessed 04.05.2020].

Kovalchuk I. V. (2019). Legal aspects of ensuring the concept of sustainable rural development policy. Regional Policy: Political and Legal Foundations, Urban Planning, Spatial Planning, Architecture. Kiev. 2019. 139-143

Kovalchuk I. V. (2019). European experience of regulatory support for the concept of sustainable rural development policy: an ecological aspect. Environmental Policy and EU Law and their Implementation in the Legal System of Ukraine. Kiev. 2019. 188-189.

Kovalchuk I. V. (2019). Legal support of the concept of sustainable rural development policy. Agrarian Policy of the European Union: Challenges and Prospects: monograph. Kiev: Center for Educational Literature. 2019. 215-226.

Kropivko M. (2014). Organization and planning of complex development of agro-industrial production and rural territories in the conditions of decentralization of powers. APK economy. 2014. №7. P. 109120.

Melnyk O. G., Kovalchuk I.V., Brovko N.I. (2018). Sustainable Land Use Development of Agricultural Land in Conditions of Decentralization in Ukraine. Features of adaptation of the legislation of Moldova and Ukraine to the legislation of the European Union. Chisinau. 2018. Available from: http://rep.btsau.edu.ua/bitstream/BNAU/1682/1/Sustainable and U.pdf $\quad$ [Accessed 04.05.2020].

Ministry of Agrarian Policy of Ukraine (2007). Register of agricultural advisory services. Available from: http://minagro.gov.ua/page/?5327 [Accessed 04.05.2020].

Ministry of Agrarian Policy of Ukraine (2008). On approval of the Procedure and terms of holding a competition for the provision of socially directed advisory services. Available from: https://zakon.rada.gov.ua/laws/show/z0289-08 [Accessed 04.05.2020].

Ministry of Agrarian Policy of Ukraine (2008). Regulations of the Regional Qualification Commission for the examination of the level of knowledge and practical skills of the Agricultural Advisory and Appeal Commission. https://zakon.rada.gov.ua/laws/show/z0546-08 [Accessed 04.05.2020]. 
Roven V. (2016). The economic and legal nature of the Agricultural Advisory Institute. Scientific Bulletin of Uzhgorod National University. Right series. 2016. Vol. 41. T. 4. P. 121-124.

Taranenko L. S. (2011). Peculiarities of rendering legal services to agricultural entities by agricultural advisory service: legal aspects. Bulletin of Kharkiv National University. Series: Right. 2011. № 945. 187192.

Van den Ban A.W., Hawkins H.S. (1999). Agricultural Extension. 2-nd. Oxford: Blackwell. 1999. 216.

Verkhovna Rada of Ukraine (2003). Commercial Code of Ukraine. Available from: https://zakon.rada.gov.ua/laws/show/436-15 [Accessed 04.05.2020].

Verkhovna Rada of Ukraine (2003). The Civil code of Ukraine. Available from: https://zakon.rada.gov.ua/laws/show/435-15 [Accessed 04.05.2020].

Verkhovna Rada of Ukraine (2004). On Agricultural Advisory Activities. Available from: https://zakon.rada.gov.ua/laws/show/1807-15 [Accessed 04.05.2020].

Verkhovna Rada of Ukraine (2010). On Amendments to the Law of Ukraine «On Agricultural Advisory Activities». Available from: https://zakon.rada.gov.ua/laws/show/2754-17 [Accessed 04.05.2020].

Verkhovna Rada of Ukraine (2011). About the List of documents of the permitting character in the sphere of economic activity. Available from: https://zakon.rada.gov.ua/laws/show/3392-17 [Accessed 04.05.2020].

Verkhovna Rada of Ukraine (2012). On amendments to some legislative acts of Ukraine concerning the activities of the Ministry of Agrarian Policy and Food of Ukraine, the Ministry of Social Policy of Ukraine, other central executive bodies, whose activities are directed and coordinated through the respective ministers. Available from: https://zakon.rada.gov.ua/laws/show/1807-15 [Accessed 04.05.2020].

Verkhovna Rada of Ukraine (2014). Association Agreement between the European Union and Ukraine. Available from: https://www.kmu.gov.ua/storage/app/media/uploaded-files/TITLE\%20IV.pdf [Accessed 04.05.2020].

Zamoysky I. (1982). Efficiency of economic and legal work. K .: Science. opinion, 1982. 170.

Zhilin V.V. Beschastnova N.V (2009). Organizational-economic aspects of increase of efficiency of advisory services. Ufa: Guillem, 2009. 184. 